\title{
НЕПРЯМА РЕВАСКУЛЯРИЗАЦІЯ ПРИ ДІАБЕТИЧНІЙ МІКРОАНГІОПАТІЇ - ВІД ЕКСПЕРИМЕНТАЛЬНИХ МОДЕЛЕЙ ДО КЛІНІЧНОГО ЗАСТОСУВАННЯ
}

Вступ. Непряму реваскуляризацію при діабетичній мікроангіопатії розглядають як перспективний напрямок лікування та профрілактики ускладнень цукрового діабету, проте теоретичне підґрунтя цього підходу недостатньо опрацьовано.

Мета дослідження - оцінити ефрективність комбінованої непрямої реваскуляризації в щурів з мікроангіопатією кінцівок на тлі експериментального стрептозотоцинового діабету.

Методи дослідження. Дослідження було виконано за умов хронічного експерименту на 100 щурах лінії Вістар масою 180-250 г. Після введення стрептозотоцину з експерименту виключали тварин з підвищеною резистентністю до панкреатотропної токсичної дії за критерієм відсутності гіперглікемії, після чого впродовж 6-ти тижнів виводили по 2 тварини для виконання морфологічних досліджень. На 7-му тижні з експерименту вивели ще 10 щурів для оцінки ефективності експериментальної моделі. 3 решти тварин ( $n=60)$ сорормували три експериментальні групи: 1-ша (контрольна) - щури зі стрептозотоциніндукованою ангіопатією без лікування (n=10); 2-га - щури зі стрептозотоциніндукованою ангіопатією, яким з лікувальною метою вводили пентоксифрілін (100 мг/ка внутрішньочеревно щоденно протягом 10-ти днів) (n=25); 3-тя - щури зі стрептозотоциніндукованою ангіопатією, яким з лікувальною метою сумісно вводили плазму, збагачену тромбоцитами (в праву задню кінцівку, одноразово, об'ємом 0,2 мл, лінійно, ретроградно, з двох точок), та пентоксиярілін (100 мг/кг внутрішньочеревно щоденно протягом 10-ти днів) (n=25). Через 4 тижні після початку експериментальної терапії з експерименту виводили по 5 тварин. Загальна його тривалість становила 110 днів.

Результати й обговорення. При експериментальному стрептозотоциновому діабеті на 8-му тижні у тварин розвинулася мікроангіопатія кінцівок. Ізольоване введення пентоксифріліну за реваскуляризуючою активністю поступалося комбінованій терапії. Комбінована терапія із застосуванням пентоксифріліну та плазмофріліну призвела до зменшення периваскулярного набряку і збільшення ефективного васкулярного об'єму переважно за рахунок зниження інтенсивності запальних проявів.

Висновок. Обговорюється питання щодо доцільності клінічного використання при лікуванні проявів діабетичної мікроангіопатії комбінації пентоксифріліну та плазми, збагаченої тромбоцитами, як засобу непрямої реваскуляризації.

КЛЮЧОВІ СЛОВА: цукровий діабет; діабетична мікроангіопатія; пентоксифілін; плазма, збагачена тромбоцитами; непряма реваскуляризація; стрептозотоцин; експериментальна модель.

ВСТУП. Цукровий діабет - одне з перших захворювань, відомих людству [1-4]. Найбільш ранні описи подібного до нього за симптомами розладу датуються 1550 р. до нашої ери - в одному з єгипетських медичних папірусів ідеться про захворювання з "надмірним утворенням сечі" [2]. Дослідженнями діабету займались лікарі Стародавньої Греції, Риму, Індії, Персії, Китаю [3-6]. До середини XIX ст. переважала думка про те, що цукровий діабет $є$ захворюванням нирок. Значний внесок у встановлення його істинної природи зробили такі дослідники, як Томас Вілліс та Метью Добсон. Т. Вілліс 1674 р. (с Р. С. Вастьянов, О. В. Чехлова, М. В. Чехлов, 2020. став відрізняти цукровий діабет від інших типів поліурії за солодким смаком сечі й помітив, що він спершу з'являється у крові. Приблизно через 100 років після цього М. Добсон показав, що при діабеті і сеча, і кров містять велику концентрацію цукру [4].

Уперше експериментально відтворити цукровий діабет вдалось 1889 р. Йозефру фон Мерінгу та Оскару Мінковському шляхом видалення підшлункової залози в собаки [7]. Завдяки їх дослідженню, а також відкриттю 1921 р. Фредеріком Бантингом та Чарльзом Гербертом Бестом інсуліну діабет стали вважати хворобою ендокринної системи. 31922 р. інсулін вико- 
ристовують для лікування цукрового діабету, що дозволило значно покращити тривалість та якість життя пацієнтів [4]. Утім сьогодні діабет крокує світом семимильними кроками. При цьому в епідеміології цукрового діабету відбулися певні зміни - він тепер не є захворюванням виключно країн "золотого мільярда", найбільші темпи приросту захворюваності відзначають у країнах з невисоким рівнем доходу $[1-3,6]$.

За оцінкою експертів ВОО3, у 2014 р. від цукрового діабету страждали 422 млн дорослих у світі порівняно зі 108 млн у 1980 р. Глобальний рівень захворюваності на цукровий діабет (стандартизовано за віком) збільшився з 4,7 до 8,5 \% серед дорослого населення. У 2012 р. діабет став причиною 1,5 млн смертельних випадків. Зі сталою гіперглікемією асоційовано ще 2,2 млн смертей, зумовлених підвищеним ризиком виникнення серцево-судинних та інших захворювань. Із цих 3,7 млн смертей 43 \% припадають на осіб, молодших 70 років. Найчастіше реєструють випадки цукрового діабету 2 типу, причому якщо раніше діабет цього типу виявляли виключно серед дорослих, то тепер його нерідко діагностують у дітей та підлітків [8, 9].

За даними МО3, в Україні живуть близько 1300000 хворих на цукровий діабет, з них близько 200000 осіб потребують щоденного використання інсуліну. Понад 100000 українців щороку вперше в житті дізнаються про таку хворобу. Число випадків зростає з року в рік, але на сьогодні майже в половини хворих на цукровий діабет захворювання вчасно не діагностують [10].

У своїй першій Глобальній доповіді по діабету ВООЗ наголошує на величезних масштабних проблемах діабету і наявності потенціалу для змін. Упорядковано політичну основу для прийняття схвалених дій щодо боротьби з цим захворюванням, і її було розглянуто з метою поліпшення ситуації. Перед світовою спільнотою поставлено амбіціозну мету - до 2030 р. скоротити на третину смертність від неінорекційних захворювань, включаючи діабет, шляхом розширення спектра медико-санітарних послуг та забезпечення доступності основних лікарських засобів [9].

На жаль, хвороба збільшує смертність у 2-3 рази й істотно скорочує тривалість життя. При цьому кількість хворих щорічно зростає у всіх країнах на 5-7 \%, а кожні 12-15 років подвоюється. Такі показники змушують говорити про неінфекційну епідемію діабету у світі $[8,9]$.

Мікроангіопатія $€$ найбільш поширеним ускладненням цукрового діабету, поступово проходячи у своєму патоморорозі стадії доклінічних проявів, стадії фрункціональних змін (гіпертонус, гіпотонус, спастико-атонія), стадію орга- нічних змін і стадію виразково-некротичних та гангренозних змін. Нерідко перебіг діабетичної мікроангіопатії обтяжується коморбідними станами, в тому числі облітеруючим атеросклерозом кінцівок [11, 12].

На сьогодні відсутня єдина точка зору відносно проблеми поєднання цукрового діабету та атеросклерозу. Деякі дослідники вважають, що цукровий діабет не просто поєднується 3 атеросклерозом, а сприяє його розвитку та прискорює прогресування [11]. Існує альтернативна думка, за якою обидва захворювання розглядають як коморбідні, що розвиваються незалежно одне від одного [12]. Утім відомо, що діабетична мікроангіопатія розвивається швидше, ніж при атеросклерозі. При цьому фрункціональний резерв мікроциркуляторного русла в основному залежить від подовженості оклюзійних ушкоджень артерій нижніх кінцівок та розвитку колатерального русла $[13,14]$. У хворих з атеросклеротичним ураженням судин нижніх кінцівок на фроні цукрового діабету хронічна артеріальна ішемія обтяжена макро- та мікроангіопатією 3 переважним дистальним типом ураження. У вказаній ситуації можливими є використання методів непрямої реваскуляризації нижніх кінцівок та стимуляція розвитку колатерального кровотоку і неоангіогенезу $[14,15]$. До методів непрямої реваскуляризації належать: поперекова симпатектомія (ПСЕ), періартеріальна симпатектомія, артеріалізація венозного кровотоку гомілки і стопи, реваскуляризуюча остеотрепанація, автогемоекстравазація, трансплантація сальника або клаптя поперечносмугастого м'яза тощо) [2, 14].

Однією 3 найбільш поширених операцій непрямої реваскуляризації досі залишається ПСЕ $[4,11,12]$. Вона була запропонована J. Diez у 1924 р. [4]. 3 того часу цей метод оперативного лікування широко використовують у пацієнтів 3 критичною ішемією нижніх кінцівок, особливо з дистальними фрормами ураження судинного русла, які власне і притаманні діабетичній мікроангіопатії. $€$ дані, що після ПСЕ відбуваються збільшення швидкості кровотоку через зниження тонусу периферичних судин, відкриття артеріовенозних шунтів і короткочасне поліпшення кровопостачання м'язів гомілки. Такий вплив на кінцівку в ряді випадків дозволяє купірувати або зменшити больовий синдром і локалізувати вогнища некрозів [15]. За даними деяких авторів, після ПСЕ кінцівку вдається зберегти в 25-45 \% випадків [4]. Інші ж автори вважають, що десимпатизація поперекової ділянки призводить до розширення судин шкіри, через що поліпшення кровопостачання кінцівки після такої операції $€$ мінімальним і нетривалим. У деяких роботах ідеться про абсолютну відсутність ефекту після 
ПСЕ, тому що не відновлюється магістральний кровотік, а фрункціональний резерв колатерального кровотоку швидко виснажується [4, 11]. На сьогодні більшість авторів не вважає ПСЕ основним методом лікування при критичній ішемії нижньої кінцівки, але є можливим її використання для зменшення больового синдрому або як доповнення до прямих реваскуляризуючих операцій.

Іншим варіантом оперативної непрямої реваскуляризації є артеріалізація венозного кровотоку. Цей підхід був неабияк популярним наприкінці XX ст. Вважали, що шляхом перев'язування стегнової або задньої великогомілкової вени можна досягти надходження крові в дистальні відділи кінцівки, збільшення припливу крові до капілярів і, відповідно, покращити оксигенацію тканин [4]. Але при оклюзії дистального русла артеріоло-венулярного пасажу оксигенованої крові не відбувається, тому артифріціальна венозна гіпертензія не чинить позитивного впливу на ішемізовану кінцівку [11]. Артеріалізації венозного русла можна домогтися також, наклавши артеріовенозні фрістули. Утім до кінця 80-х років минулого століття цей вид оперативного лікування в більшості випадків не давав бажаного результату [11, 12]. У 1993 р. Z. Q. Wu та ін. розробили методику операції, яка виявилася, за даними авторів, ефективною більш ніж у 90 \% випадків [4]. Однак у подальшому, при порівнянні результатів консервативної терапії та артеріалізації венозної системи, було виявлено незначні відмінності за відсотком збереження кінцівки (54 проти 57 \% відповідно) [4].

Існує велика кількість робіт, присвячених розробці паліативних втручань на кістках нижніх кінцівок для лікування захворювань периферичних артерій [4]. Реваскуляризуючу остеотрепанацію виконують у зоні найкращого кровопостачання трубчастих кісток для поліпшення кровообігу в м'яких тканинах нижніх кінцівок у хворих 3 критичною ішемією нижніх кінцівок [14]. На думку одних авторів, есрективність цієї операції полягає в утворенні екстраанатомічних зв'язків між колатеральною мережею м'яких тканин і внутрішньокістковими артеріями за допомогою трепанаційних отворів [4, 14]. Інші вважають, що зменшення або зникнення больового синдрому пов'язане зі зниженням внутрішньокісткового тиску після реваскуляризуючих остеотрепанацій [4]. Також існують операції, що стимулюють ріст колатеральних судин у зоні ішемії. До них належить імплантація тканин з добре розвинутим кровопостачанням, наприклад, імплантація великого сальника і пересадження клаптя найширшого м'яза спини або переднього зубчастого м'яза на м'язи гомілки $[4,12]$.
У літературі є дані щодо застосування для непрямої реваскуляризації лікарських засобів [14-16]. До них належать похідне метилксантину - пентоксифілін (призначають у дозі 100300 мг/добу парентерально або по 400 мг перорально 2-3 рази на добу) та синтетичний аналог PgE1 - алпростадил (призначають у дозі 20-60 мкг внутрішньовенно 1-2 рази на добу). Продовжується пошук й інших засобів неоперативного лікування діабетичної мікроангіопатії, спрямованого на непряму реваскуляризацію [17, 18]. Утім жодна з існуючих моделей експериментального цукрового діабету (ЕЦД) не враховує специфріки патоморфозу цукрового діабету і діабетичної мікроангіопатії, що утруднює впровадження еорективних методів лікування цих патологічних станів [19-25].

Мета дослідження - оцінити есрективність комбінованої непрямої реваскуляризації в щурів 3 мікроангіопатією кінцівок на тлі експериментального стрептозотоцинового діабету.

МЕТОДИ ДОСЛІДЖЕННЯ. Дослідження було виконано за умов хронічного експерименту на 100 щурах лінії Вістар масою 180-250 г. Після введення стрептозотоцину з експерименту виключали тварин $з$ підвищеною резистентністю до панкреатотропної токсичної дії за критерієм відсутності гіперглікемії, після чого впродовж 6-ти тижнів виводили по 2 тварини для виконання морфологічних досліджень. На 7-му тижні 3 експерименту вивели ще 10 щурів для оцінки ефрективності експериментальної моделі. 3 решти тварин (n=60) сорормували три експерименн тальні групи: 1-ша (контрольна) - щури зі стрептозотоциніндукованою ангіопатією без лікування (n=10); 2-га - щури зі стрептозотоциніндуковав ною ангіопатією, яким з лікувальною метою вводили пентоксифілін (100 мг/кг внутрішньочеревно щоденно протягом 10-ти днів) $(n=25) ; 3$-тя - щури зі стрептозотоциніндукованою ангіопатією, яким з лікувальною метою сумісно вводили плазму, збагачену тромбоцитами (в праву задню кінцівку, одноразово, об'ємом 0,2 мл, лінійно, ретроградно, з двох точок), та пентоксифілін (100 мг/кг внутрішньочеревно щоденно протягом 10-ти днів) $(\mathrm{n}=25)$.

Через 4 тижні після початку експериментальної терапії з експерименту виводили по 5 тварин. Загальна його тривалість становила 110 днів.

Підготовку тварин, усі втручання, знеболювання та виведення з експерименту здійснювали у повній відповідності до вимог Методичних рекомендацій ДФЦ МОЗ України (Київ, 2001), а також правил GLP, які передбачила Європейська комісія 3 нагляду за проведенням лабораторних та інших досліджень, згідно з Кодексом вченого 
України. Евтаназію щурів проводили з урахуванням положень, регламентованих додатком № 8 "Правила гуманного поводження 3 лабораторними тваринами", Санітарних правил з обладнання, устаткування й утримування експериментально-біологічних клінік (віваріїв) № 1045-73 [26].

Лабораторних щурів утримували в індивідуальних боксах з 12-годинною зміною світла і темряви, вологістю повітря $60 \%$, постійною температурою $(22 \pm 1){ }^{\circ} \mathrm{C}$, вільним доступом до води та їжі.

Експериментальний цукровий діабет відтворювали в щурів шляхом внутрішньочеревного введення їм стрептозотоцину (60 мг/кг; "Alfa Aesar", США, [J61601, Lot: F30X011]), який розчиняли у натрієвому цитратному буфері $(\mathrm{pH}=4,5)$.

Масу тіла щурів визначали в грамах на спеціальних механічних лабораторних терезах ВЛ-120 (Томськ, Росія), похибка методу становила \pm 100 мг.

Аналіз сечі проводили за допомогою діагностичних тест-смужок CITOLAB 3GK (Pharmasco, Україна). Глюкозу й ацетон у сечі визначали у ммоль/л, білок у сечі - у г/л. Вміст глюкози у крові визначали глюкозидним методом [27].

Для подальших досліджень обирали лише тих щурів, концентрація глюкози в крові яких перевищувала 12 ммоль/л. Ефективність моделювання ЕЦД становила 92-95 \% (у середньому лише в одного щура з 20-ти концентрація глюкози в крові на 2-гу добу після введення стрептозотоцину була меншою 10 ммоль/л).

Кількість глюкози в крові та сечі, а також ацетону і білка в сечі після ін'єкції препарату визначали на 1-шу, 3-тю і 7-му доби, а потім раз на тиждень упродовж наступних 8-ми тижнів до фрормування експериментальної діабетичної ангіопатії.

За щурами спостерігали 8 тижнів без лікування (цей часовий інтервал є достатнім для фрормування експериментальної діабетичної ангіопатії), після чого розпочинали лікування. Препарати з лікувальною метою тваринам з ЕДА вводили, починаючи з 53-го дня експерименту [19].

Формування експериментальної діабетичної ангіопатії підтверджували морфологічним дослідженням м'яких тканин задніх кінцівок щурів (з цією метою кожного тижня утилізували по 2 тварини з кожної групи).
Плазму, збагачену тромбоцитами, отримували за стандартною методикою, після приготування негайно вводили в праву задню кінцівку щурів 3-ї групи об'ємом 0,2 мл лінійно ретроградно $з$ двох точок.

Статистичну обробку проводили непараметричними методами за допомогою програмного забезпечення Statistica 10.0 (Dell StatSoft Inc., США) [28].

РЕЗУЛЬТАТИ Й ОБГОВОРЕННЯ. СереДНЯ маса експериментальних тварин становила $(190,0 \pm 0,6)$ г при с $=2,9$ \%. Під час аналізу розподілу значень вмісту глюкози в крові щурів після введення стрептозотоцину встановлено, що при амплітуді значень 9,9-17,0 ммоль/л (табл.) у середньому цей показник становив $(14,2 \pm 0,2)$ ммоль/л.

Подальший аналіз показав, що ефективність моделювання ЕЦД становила $92 \%$, що є прийнятним для підгострого експерименту [19].

На тлі ЕЦД тварини були млявими, апатичними, в них відзначали полідипсію та поліурію.

Проведений експрес-аналіз вмісту глюкози в сечі, а також ацетону і білка в сечі показав швидкий розвиток ознак діабетичної нефропатії. Уже наприкінці 1-го тижня екскреція білка в сечі перевищувала 25 мг на добу, становлячи в середньому $(25,7 \pm 0,4)$ мг/добу, а до кінця 2-го місяця спостереження збільшилася до $(27,9 \pm 0,3)$ мг/добу. Щодо вмісту глюкози, то у всіх експериментальних тварин він перевищував 2 \%, що відповідало середньому рівню $(11,1 \pm 0,3)$ ммоль/л.

У 56,3 \% випадків якісним методом визначали ацетонурію, яка свідчила про наявність кетоацидозу. Втім загальний стан тварин погіршувався незначно, превалювали загальні поведінкові зміни, характерні для ЕЦД.

Таким чином, створена експериментальна модель адекватно відображає особливості цукрового діабету середнього ступеня тяжкості у стадії декомпенсації [22-24], що дозволяє вважати подальші висновки щодо перебігу діабетичної мікроангіопатії за умов експериментальної терапії достатньо обґрунтованими.

Результати дослідження показали, що в щурів 1-ї групи відбувалися суттєві зміни у всіх шарах шкіри, які частково нівелювалися при проведенні експериментальної терапії, спрямо-

Таблиця - Рівень глікемії (ммолыл) у тварин після введення стрептозотоцину

\begin{tabular}{|l|c|c|c|}
\hline \multirow{2}{*}{ Рівень глікемії } & \multicolumn{3}{|c|}{ Група тварин } \\
\cline { 2 - 4 } & 1-ша & 2-га & 3-тя \\
\hline Після введення стрептозотоцину & $14,5 \pm 0,6$ & $13,9 \pm 0,3$ & $14,3 \pm 0,3$ \\
\hline Наприкінці 1-го тижня експерименту & $14,8 \pm 0,5$ & $14,4 \pm 0,4$ & $14,6 \pm 0,3$ \\
\hline
\end{tabular}


ваної на непряму реваскуляризацію ішемізованих тканин.

Як свідчать отримані результати, за умов відтворення цукрового діабету вже через 6 тижнів у щурів розвивалася типова картина діабетичної мікроангіопатії. Крім дистросрічних змін шкіри, у тварин спостерігали явища діабетичної периферичної полінейропатії, яка проявлялася слабкістю кінцівок та зменшенням ресрлекторної відповіді на щипкове подразнення [27]. Відзначали також ознаки температурної гіпералгезії.

Так, вираження периваскулярного інфрільтрату було найменшим у 3-й групі - $(3,6 \pm 0,3)$ мкм (рис. 1). Цей показник виявився у 2,2 раза ниж- чим, ніжу щурів контрольної групи, $-(7,9 \pm 0,8)$ мкм та на $39 \%$ меншим, ніж у тварин 2-ї групи, $(5,9 \pm 0,6)$ мкм $(p<0,05)$.

щодо діаметра судин у фрокусі ішемії при діабетичній мікроангіопатії на фоні ЕЦД, то у 2-й і 3-й групах він практично не відрізнявся (рис. 2), становивши, відповідно, $(11,5 \pm 0,9)$ та $(11,6 \pm 0,6)$ мкм (у контрольній групі цей показник дорівнював $(7,7 \pm 0,7)$ мкм). Що стосується питомого об'єму судин мікроциркуляторного русла, то він при проведенні медикаментозної непрямої реваскуляризації збільшився $3(3,2 \pm 0,2) \%$ у контрольній групі до $(3,9 \pm 0,3) \%$ у 2-й групі (застосування виключно пентоксифріліну) та до

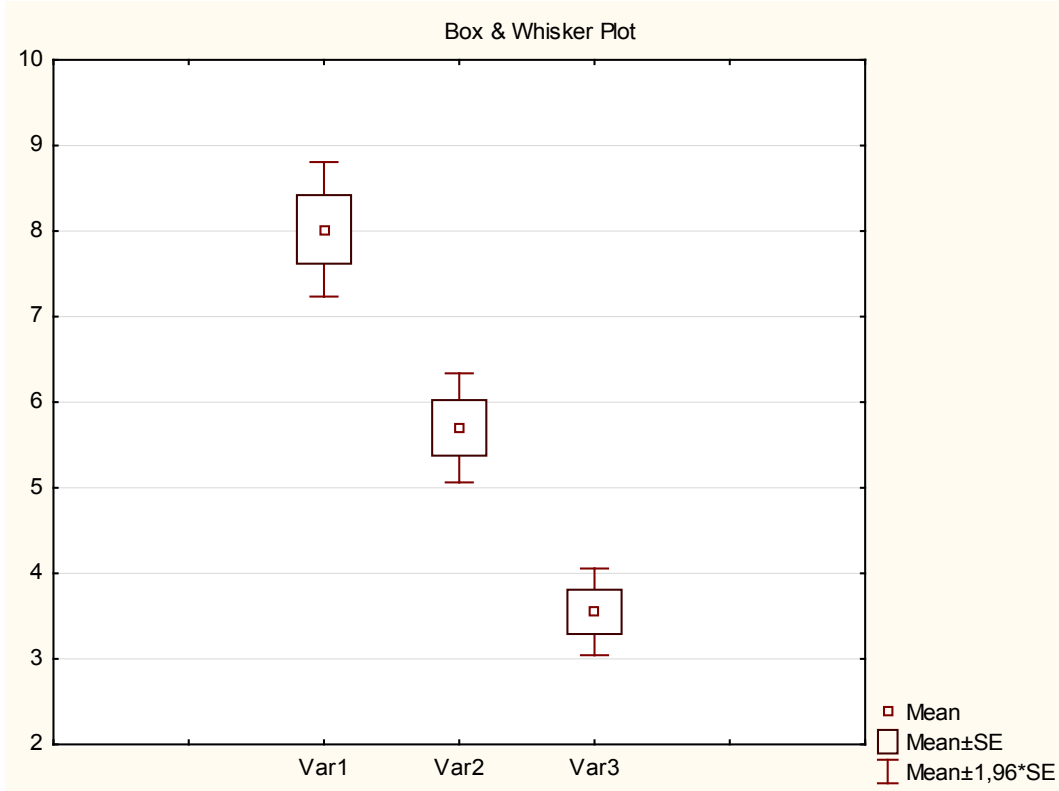

Рис. 1. Товщина периваскулярного інфільтрату в групах порівняння (мкм).

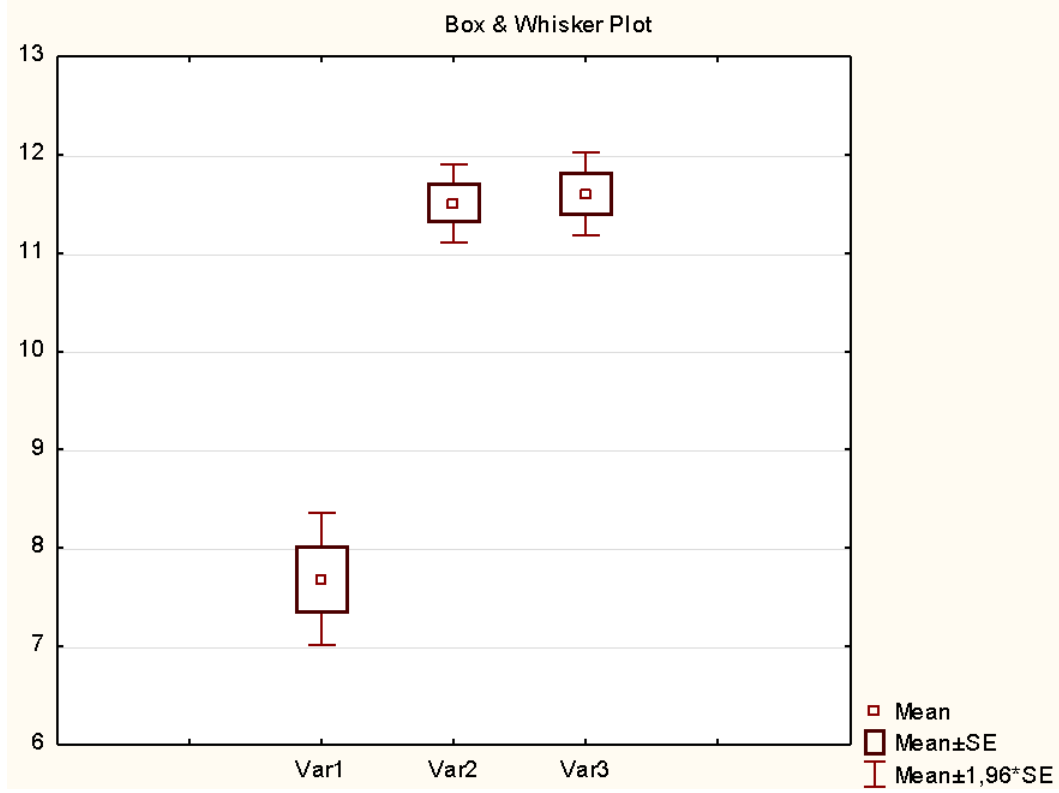

Рис. 2. Діаметр судин при діабетичній мікроангіопатії нижніх кінцівок (мкм). 
$(4,4 \pm 0,3) \%$ - у 3-й (комбінована терапія пентоксифіліном та плазмою, збагаченою тромбоцитами).

Таким чином, периваскулярний набряк у 3-й групі зменшувався не стільки за рахунок вазодилатації, як через зменшення інтенсивності запальних проявів. Цей френомен можна пояснити високим вмістом у плазмі, збагаченій тромбоцитами, біологічно активних сполук, у тому числі тих, що безпосередньо впливають на продукування цитокінів та клітинну проліферацію $[14,17,18]$.

Як відомо, діабетична мікроангіопатія характеризується ураженням переважно судин мікроциркуляторного русла [11-13]. Таким чином, покращення мікроциркуляції може уповільнити розвиток ангіопатії та, відповідно, поліпшити репаративну здатність ушкоджених тканин.
ВИСНОВКИ. 1. При експериментальному стрептозотоциновому діабеті на 8-му тижні у тварин розвивається мікроангіопатія кінцівок.

2. Ізольоване введення пентоксисріліну за реваскуляризуючою активністю поступається комбінованій терапії.

3. Комбінована терапія із застосуванням пентоксифріліну та плазмофріліну призводить до зменшення периваскулярного набряку і збільшення ефективного васкулярного об'єму переважно за рахунок зменшення інтенсивності запальних проявів.

4. Результати роботи можуть бути експериментальним обґрунтуванням доцільності клінічного застосування комбінації пентоксифіліну та плазми, збагаченої тромбоцитами, при лікуванні проявів діабетичної мікроангіопатії.

\section{СПИСОК ЛІТЕРАТУРИ}

1. Ahmed A. M. History of diabetes mellitus. - Saudi. Med. J. - 2002. - 23 (4). - P. 373-378.

2. Guaraldi F. Diabetes: From Ancient Egypt to the 18th century / F. Guaraldi, R. Pasquali // J. Assoc. Physicians India. - 2015. - 63 (3). - P. 128.

3. Milestones in the history of diabetes mellitus: The main contributors / M. Karamanou, A. Protogerou, G. Tsoucalas [et al.] // World J. Diabetes. - 2016. - 7 (1). - P. 1-7.

4. Medvei V. C. The history of clinical endocrinology : a comprehensive account of endocrinology from earliest times to the present day / V. C. Medvei. - Carnforth : Parthenon, 1993. - P. 23-34.

5. Aretaeus of Cappadocia and the first description of diabetes / K. Laios, M. Karamanou, Z. Saridaki, G. Androutsos // Hormones (Athens). - 2012. - 11 (1). P. 109-113.

6. Valenti G. History of Diabetes Insipidus / G. Valenti, G. Tamma // G. Ital. Nefrol. - 2016. - 33, Suppl. 66. P. 33.S66.1

7. Von Mehring J. "Diabetes mellitus nach pankreasexstirpation" / J. Von Mehring, O. Minkowski // Arch. Exp. Pathol. Pharmakol. - 1890. - 26 (5-6). - P. 371-387.

8. Tao Z. Epidemiological Perspectives of Diabetes / Z. Tao, A. Shi, J. Zhao // Cell Biochem. Biophys. -2015. 73 (1). - P. 181-185.

9. Global prevalence of diabetes: estimates for the year 2000 and projections for 2030 / S .Wild, G. Roglic, A. Green [et al.] // Diabetes Care. - 2004. - 27 (5). P. 1047-1053.

10. Germanyuk T. A. The study of the effectiveness of the combined therapy of diabetes mellitus based on the pharmacoeconomic analysis in Ukraine / T. A. Germanyuk, T. I. Ivko, L. O. Bobrytska // Вісник фрармації. 2018. - № 3. - C. 49-53.

11. Pérez-Díaz I. Diabetes mellitus / I. Pérez-Díaz // Gac. Med. Mex. - 2016. - 152, Suppl 1. - P. 50-55.
12. Polsky S. Obesity, insulin resistance, and type 1 diabetes mellitus / S. Polsky, S. L. Ellis // Curr. Opin. Endocrinol. Diabetes Obes. - 2015. - 22 (4). - P. 277282.

13. Diabetic microvascular disease: An Endocrine Society Scientific Statement / E. J. Barrett, Z. Liu, M. Khamaisi [et al.] // J. Clin. Endocrinol. Metab. -2017. 102 (12). - P. 4343-4410.

14. A systematic review and meta-analysis of adjunctive therapies in diabetic foot ulcers / T. Elraiyah, A. Tsapas, G. Prutsky [et al.] // J. Vasc. Surg. -2016. -63 (2 Suppl). - P. 46S-58S.e1-2

15. Agrawal N. K. Targeting inflammation in diabetes: Newer therapeutic options / N. K. Agrawal, S. Kant // World J. Diabetes. - 2014. - 5 (5). - P. 697-710.

16. Мохорт Т. В. Хронические осложнения сахарного диабета : фокус на пентоксифиллин / Т. В. Мохорт // Мед. новости. - 2015. - № 4. - С. 4-9.

17. Platelet-rich plasma for the treatment of clean diabetic foot ulcers / M. Ahmed, S. A. Reffat, A. Hassan, F. Eskander // Ann. Vasc. Surg. - 2017. - 38. - P. 206211.

18. Autologous platelet-rich plasma for treating chronic wounds / M. J. Martinez-Zapata, A. J. MartíCarvajal, I. Solà [et al.] // Cochrane Database Syst. Rev. - 2016. - (5). - P. CD006899.

19. Стрептозотоциновые модели сахарного диабета / В. К. Мазо, Ю. С. Сидорова, С. Н. Зорин, А. А. Кочеткова // Вопросы питания. - 2016. - 85, № 4. - C. 14-21.

20. Experimental diabetes mellitus in different animal models / A. Al-Awar, K. Kupai, M. Veszelka [et al.] // J. Diabetes Res. - 2016. - 2016. - P. 9051426.

21. The inhibitory $\mathrm{G}$ protein $\alpha$-subunit, $g \alpha z$, promotes type 1 diabetes-like pathophysiology in NOD mice / R. J. Fenske, M. T. Cadena, Q. E. Harenda [et al.] // Endocrinology. - 2017. - 158 (6). - P. 1645-1658. 
22. Furman B. L. Streptozotocin-induced diabetic models in mice and rats / B. L. Furman // Curr. Protoc. Pharmacol. - 2015. - 70, Issue 1. - P. 5.47.1-20.

23. Animal models of diabetic macrovascular complications: key players in the development of new therapeutic approaches / S. E. Heinonen, G. Genové, E. Bengtsson [et al.] // J. Diabetes Res. - 2015. - 2015. P. 404085.

24. King A. Animal models for diabetes: Understanding the pathogenesis and finding new treatments / A. King, J. Bowe // Biochem. Pharmacol. - 2016. - 99. P. 1-10.
25. King A. J. The use of animal models in diabetes research / A. J. King // Br. J. Pharmacol. - 2012. 166 (3). - P. 877-894.

26. Антологія біоетики / за ред. Ю. Кундієва. Львів : Бак, 2003. - 592 с.

27. Кишкун А. А. Клиническая лабораторная диагностика / А. А. Кишкун. - М. : ГЭОТАР-Медиа, 2008. - 720 c.

28. Боровиков В. П. Statistica - Статистический анализ и обработка данных в среде Windows / В. П. Боровиков, И. П. Боровиков. - М. : Инорормац.издат. дом “Филинъ”, 1998. - 608 с.

\section{REFERENCES}

1. Ahmed, A.M. (2002). History of diabetes mellitus. Saudi Med. J., 23 (4), 373-378.

2. Guaraldi, F., \& Pasquali, R. (2015). Diabetes: From Ancient Egypt to the 18th century. J. Assoc. Physicians India, 63 (3), 128.

3. Karamanou, M., Protogerou, A., Tsoucalas, G., Androutsos, G., \& Poulakou-Rebelakou, E. (2016). Milestones in the history of diabetes mellitus: The main contributors. World J. Diabetes, 7 (1), 1-7.

4. Medvei, V.C. (1993). The history of clinical endocrinology: a comprehensive account of endocrinology from earliest times to the present day. Carnforth: Parthenon.

5. Laios, K., Karamanou, M., Saridaki, Z., \& Androutsos, G. (2012). Aretaeus of Cappadocia and the first description of diabetes. Hormones (Athens), 11 (1), 109113.

6. Valenti, G., \& Tamma, G. (2016). History of diabetes insipidus. G. Ital. Nefrol., 33 (66), 33, 66.1

7. Von Mehring, J., \& Minkowski, O. (1890). "Diabetes mellitus nach pankreasexstirpation". Arch. Exp. Pathol. Pharmakol., 26 (5-6), 371-387.

8. Tao, Z., Shi, A., \& Zhao, J. (2015). Epidemiological perspectives of diabetes. Cell Biochem. Biophys. , 73 (1), 181-185.

9. Wild, S., Roglic, G., Green, A., Sicree, R., \& King, H. (2004). Global prevalence of diabetes:estimates for the year 2000 and projections for 2030. Diabetes Care, 27 (5), 1047-1053.

10. Germanyuk, T.A., Ivko, T.I., \& Bobrytska, L.O. (2018). The study of the effectiveness of the combined therapy of diabetes mellitus based on the pharmacoeconomic analysis in Ukraine. Visnyk farmatsii - News of Pharmacy, 3, 49-53.

11. Pérez-Díaz, I. (2016). Diabetes mellitus. Gac. Med. Mex, 152 (1), 50-55

12. Polsky, S., \& Ellis, S.L. (2015). Obesity, insulin resistance, and type 1 diabetes mellitus. Curr. Opin. Endocrinol. Diabetes Obes., 22 (4), 277-282.

13. Barrett, E.J., Liu, Z., Khamaisi, M., King, G.L., Klein, R., Klein, B.E.K., ..., \& Casellini, C.M. (2017). Diabetic microvascular disease: An Endocrine Society
Scientific Statement. J. Clin. Endocrinol. Metab., 102 (12), 4343-4410.

14. Elraiyah, T., Tsapas, A., Prutsky, G., Domecq, J.P., Hasan, R., Firwana, B., ... Murad, M.H. (2016). A systematic review and meta-analysis of adjunctive therapies in diabetic foot ulcers. J. Vasc. Surg., 63 (2), 46S-58S.e1-2

15. Agrawal, N.K., \& Kant, S. (2014). Targeting inflammation in diabetes: Newer therapeutic options. World J. Diabetes, 5 (5), 697-710.

16. Mokhort, T.V. (2015). Khronicheskiye oslozhneniya sakharnogo diabeta: fokus na pentoksifillin [Chronic complications of diabetes mellitus: focus on pentoxifylline]. Meditsinskiye novosti-Medical News, 4, 4-9 [in Russian].

17. Ahmed, M., Reffat, S.A., Hassan, A., \& Eskander, F. (2017). Platelet-rich plasma for the treatment of clean diabetic foot ulcers. Ann. Vasc. Surg., 38, 206211.

18. Martinez-Zapata, M.J., Martí-Carvajal, A.J., Solà, I., Expósito, J.A., Bolíbar, I., Rodríguez, L., ..., Zaror, C. (2016). Autologous platelet-rich plasma for treating chronic wounds. Cochrane Database Syst. Rev., (5), CD006899.

19. Mazo, V.K. Sidorova, Yu.S., Zorin, S.N., \& Kochetkova, A.A. (2016). Streptozototsinovyye modeli sakharnogo diabeta [Streptozotocin models of diabetes mellitus]. Voprosy pitaniya - Problems of Nutrition, 85, 4, 14-21 [in Russian].

20. Al-Awar, A., Kupai, K., Veszelka, M., Szúcs, G., Attieh, Z., Murlasits, Z., ..., \& Varga, C. (2016). Experimental Diabetes Mellitus in Different Animal Models. J. Diabetes Res., 2016, 9051426.

21. Fenske, R.J., Cadena, M.T., Harenda, Q.E., Wienkes, H.N., Carbajal, K., Schaid, M.D., ..., Kimple, M.E. (2017). The inhibitory G protein $\alpha$-subunit, gaz, promotes type 1 diabetes-like pathophysiology in NOD mice. Endocrinology, 158 (6), 1645-1658.

22. Furman, B.L. (2015). Streptozotocin-induced diabetic models in mice and rats. Curr. Protoc. Pharmacol., $70,1,5.47 .1-20$

23. Heinonen, S.E., Genové, G., Bengtsson, E., Hübschle, T., Åkesson, L., Hiss, K., ..., Gomez, M.F. (2015). Animal models of diabetic macrovascular 
complications: key players in the development of new therapeutic approaches. J. Diabetes Res., 2015, 404085.

24. King, A., \& Bowe, J. (2016). Animal models for diabetes: Understanding the pathogenesis and finding new treatments. Biochem. Pharmacol., 99, 1-10.

25. King, A.J. (2012). The use of animal models in diabetes research. Br. J. Pharmacol., 166 (3), 877-894.

26. Kundiiev, Yu. (Ed.) (2003). Antolohiia bioetyky [Anthology of bioethics]. Lviv: Bak [in Ukrainian].
27. Kishkun, A.A. (2008). Klinicheskaya laboratornaya diagnostika [Clinical laboratory diagnostics]. Moscow: GEOTAR-Media [in Russian].

28. Borovikov, V.P., \& Borovikov, I.P. (1998). Statistica - Statisticheskiy analiz i obrabotka dannykh v srede Windows [Statistica - Statistical analysis and data processing in Windows]. Moscow: Informats, izdat. dom "Filin" [in Russian].

Р. С. Вастьянов, Е. В. Чехлова, М. В. Чехлов ОДЕССКИЙ НАЦИОНАЛЬНЫЙ МЕДИЦИНСКИЙ УНИВЕРСИТЕТ

\section{НЕПРЯМАЯ РЕВАСКУЛЯРИЗАЦИЯ ПРИ ДИАБЕТИЧЕСКОЙ МИКРОАНГИОПАТИИ - ОТ ЭКСПЕРИМЕНТАЛЬНЫХ МОДЕЛЕЙ К КЛИНИЧЕСКОМУ ПРИМЕНЕНИЮ}

\section{Резюме}

Вступление. Непрямую реваскуляризацию при диабетической микроангиопатии рассматривают как перспективное направление лечения и профилактики осложнений сахарного диабета, однако теоретические основы этого подхода недостаточно обработано.

Цель исследования - оценить эффрективность комбинированной непрямой реваскуляризации у крыс с микроангиопатией конечностей на фоне экспериментального стрептозотоцинового диабета.

Методы исследования. Исследование было выполнено в условиях хронического эксперимента на 100 крысах линии Вистар массой 180-250 г. После введения стрептозотоцина из эксперимента исключали животных с повышенной резистентностью к панкреатотропному токсическому действию по критерию отсутствия гипергликемии, после чего в течение 6-ти недель выводили по 2 животных для выполнения морфологических исследований. На 7-й неделе из эксперимента вывели еще 10 крыс для оценки эфрфективности экспериментальной модели. Из оставшихся животных $(n=60)$ сфрормировали три экспериментальные группы: 1-я (контрольная) - крысы с стрептозотоцининдуцированной ангиопатией без лечения (n=10); 2-я - крысы с стрептозотоцининдуцированной ангиопатией, которым с лечебной целью вводили пентоксифриллин (100 ма/ка внутрибрюшно ежедневно в течение 10-ти дней) (n=25); 3-я крысы с стрептозотоцининдуцированной ангиопатией, которым с лечебной целью совместно вводили плазму, обогащенную тромбоцитами (в правую заднюю конечность, однократно, объемом 0,2 мл, линейно, ретроградно, из двух точек), и пентоксифиллин (100 мг/кг внутрибрюшно ежедневно в течение 10-ти дней) (n=25). Через 4 недели после начала экспериментальной терапии из эксперимента выводили по 5 животных. Общая его длительность составила 110 дней.

Результаты и обсуждение. При экспериментальном стрептозотоциновом диабете на 8-й неделе у животных развинулась микроангиопатия конечностей. Изолированное введение пентоксифиллина по реваскуляризирующей активности уступало комбинированной терапии. Комбинированная терапия с применением пентоксифиллина и плазмофрилина привела к уменьшению периваскулярного отека и увеличению эффрективного васкулярного объема преимущественно за счет снижения интенсивности воспалительных проявлений.

Вывод. Обсуждается вопрос относительно целесообразности клинического использования при лечении проявлений диабетической микроангиопатии комбинации пентоксифриллина и плазмы, обогащенной тромбоцитами, как средства непрямой реваскуляризации.

КЛЮЧЕВЫЕ СЛОВА: сахарный диабет; диабетическая ангиопатия; пентоксифиллин; плазма, обогащенная тромбоцитами; непрямая реваскуляризация; стрептозотоцин; экспериментальная модель. 


\section{INDIRECT REVASCULARIZATION IN DIABETIC MICROANGIOPATHY - FROM EXPERIMENTAL MODELS TO CLINICAL USE}

\section{Summary}

Introduction. Indirect revascularization in diabetic microangiopathy is considered as a promising direction for the treatment and prevention of complications of diabetes, but the theoretical background of this approach is insufficiently elaborated.

The aim of the study - to evaluate the effectiveness of combined indirect revascularization in rats with microangiopathy of the extremities on the background of experimental streptozocin diabetes.

Research Methods. Experimental studies were carried out in a chronic experiment on 100 Wistar rats weighing 180-250 g. After administration of streptozocin, animals with increased resistance to pancreatotropic toxicity were excluded from the experiment according to the criterion of the absence of hyperglycemia, after which they were bred for 6 weeks 2 animals for morphological studies. At week 7, another 10 animals were removed from the experiment to evaluate the effectiveness of the experimental model. Three experimental groups were formed from the remaining animals $(n=60)$. Group I (control) - rats with streptozotocin-induced angiopathy without treatment ( $n=10)$; group 2 rats with streptozotocin-induced angiopathy, were given pentoxifylline (100 mg/kg ip for 10 days) for therapeutic purposes ( $n=25) ;$ group 3 - rats with streptozotocin-induced angiopathy, which together with the treatment were injected with platelet-rich plasma (in the right hind limb, once, with a volume of $0.2 \mathrm{ml}$, linearly, retrograde, from two points) and pentoxifylline (100 mg/kg intraperitoneally within 10 days) ( $n=25) .4$ weeks after the start of the experimental therapy, 5 animals were removed from the experiment. The duration of the experiment was 110 days.

Results and Discussion. It was shown that in experimental streptozocin diabetes at 8 weeks in animals, microangiopathy of the extremities develops. It is proved that the isolated administration of pentoxifylline in the terms of revascularizing activity is inferior to combination therapy. Combined therapy with pentoxifylline and plasmofilling leads to a decrease in perivascular edema and an increase in effective vascular volume mainly due to a decrease in the intensity of inflammatory manifestations.

Conclusion. The feasibility of the clinical use of a combination of pentoxifylline and plasma enriched with platelets in the treatment of manifestations of diabetic microangiopathy as a means of indirect revascularization is discussed.

KEY WORDS: diabetes mellitus; diabetic angiopathy; pentoxifylline; platelet-rich plasma; indirect revascularization; streptozocin; experimental model.

Отримано 03.01.20

Адреса для листування: О. В. Чехлова, Одеський національний медичний університет, Валіховський пров., 2, Одеса, 650оО, Україна, e-mail: doctorchekhlova@gmail.com. 